\title{
レーザー加工のインテリジェント化
}

\section{Intelligence in Laser Processing}

\author{
溝辺浩史* • 中村 強* \\ Hirofumi MIZOBE and Tsuyoshi NAKAMURA
}

Key Words: Monitoring Technology, Tracking Technology, Industry 4.0

\section{1. 緒言}

レーザーが産業用途に応用されて以降、今日までのレー ザー技術の開発は主に高出力化、高ビーム品質化を中心に 開発が進められてきた。特に過去 10 年の間は、固体レー ザーの励起方式がランプ励起から半導体方式に取って代わ り、高出力化、高ビーム品質化と共に低消費電力化と発振 器本体の小型化が著しく進んだ。また同時に低価格化も進 んだことでレーザー加工の応用範囲が広がり、新しいユー ザー層と新しいアプリケーション開発が積極的に行われて いる。

一方、レーザー加工を初めて導入検討している方々から の視点では、レーザー加工導入はまだまだ特別な専門知識 を有した職人芸的技術担当者が必須との認識が強く、特別 な技術と知識が無いと運用出来ないと認識されている。

ここ数年、様々なレーザー加工用の制御用・モニタリン グ用機器やソフトウェアが開発され、レーザー加工の自動 化が進んでいるが、レーザー加工が今後さらに一般化し、 汎用ツールとしてょり一層普及を推し進めるためには、自 動化を推進するセンサーやモニタリング技術を活用し、 レーザー装置のインテリジェント化により、レーザー設備 運用者が様々な設定やレーザー加工後の品質確認をするこ となく、レーザー設備を安定的に運用できるようになって いく必要がある。

また最近では IoTに関連し、欧州では Industry 4.0 の運用 が具現化しつつある。レーザー装置のインテリジェント化 によって得られたビッグデータを活用した生産管理、予防 保全、製品のトレーサビリティ等が標準化されようとして いる。

\section{2. モニタリング技術}

2.1 レーザー発振器内のモニタリング トルンプでは各種レーザー発振器を開発・製造・販売し
ている。気体レーザーとしては高速軸流型と拡散冷却型の $\mathrm{CO}_{2}$ レーザー発振器、固体レーザーとしてはディスクレー ザー、半導体レーザー、ファイバーレーザー、ランプ励起 $\mathrm{Nd}: \mathrm{YAG}$ パルスレーザー、極短パルスレーザー、レーザー マーカーなど各種レーザー発振器を取り揃えている。

トルンプではこれらのレーザー発振器の中で、ディスク レーザーの技術を応用した多くの製品をリリースしている。

ディスクレーザーは薄い円盤状のレーザー媒質に半導体 レーザーからの励起光を照射してレーザーを発振する ${ }^{1)} 。$ レーザー媒質は裏面からヒートシンクで冷却し、冷却性能 を高めることで熱レンズ効果を最小限化し、高出力かつ高 ビーム品質のレーザー発振を可能にしている ${ }^{1)}$ キャビティ から出射されたレーザーはファイバに導入され、出射光学 系まで伝送される。ディスクレーザーは発振器内の各所に 光学系部品のセンサーの配置により、出力の安定性や異常 個処の検知を図ってきた。検知センサーはそれぞれの光学 系部品からの散乱光を検出することにより光学系部品の異 常やダメージを検出し、またレーザー発振器内の冷却水温 度を各所でモニタリングすることにより、レーザー発振器 内で発生する異常をいち早く感知して予防保全することが 可能である。Fig.1にディスクレーザー発振器の発振光学 系部を示す。

伝送用ファイバには断線検知センサーや温度センサー、 出射光学系に保護ガラスの污染検知センサーを搭載するな ど出力安定性や保全のための多数のセンサー類を組み込ん できた。これらのセンサー類は上述のように基本的には レーザーの安定運用の観点から設けられたものである。ま たレーザーセーフティの観点から、伝送用ファイバの接続 状態やレーザー発振器筐体の開閉状態も監視して、レー ザー発振が安全な環境下でのみ発振できる様なスイッチ類 も搭載している。

これまでレーザー加工機の運用は、専門的な知識が必要 であった。特にレーザーが製造現場で使用され始めた初期

*トルンプ株式会社 レーザー事業部 レーザー技術部（† 226-0006 横浜市緑区白山 1-18-2）

TRUMPF Corporation, Laser Engineering Department, Laser Division (1-18-2 Hakusan, Midori-ku, Yokohama, 226-0006 Japan) 


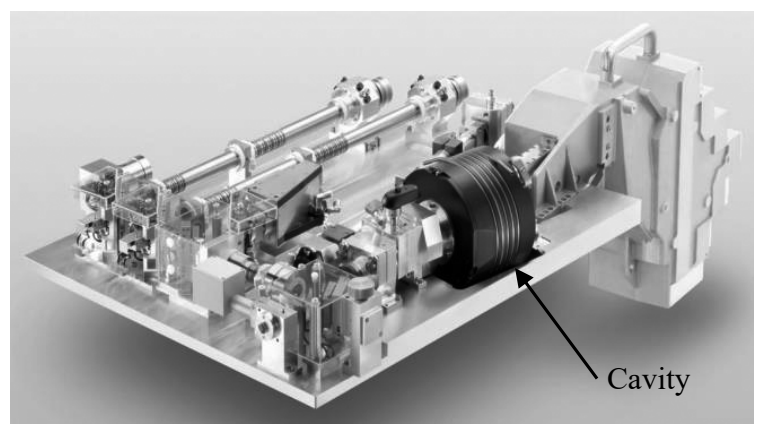

Fig.1 Structure of Disk Laser.

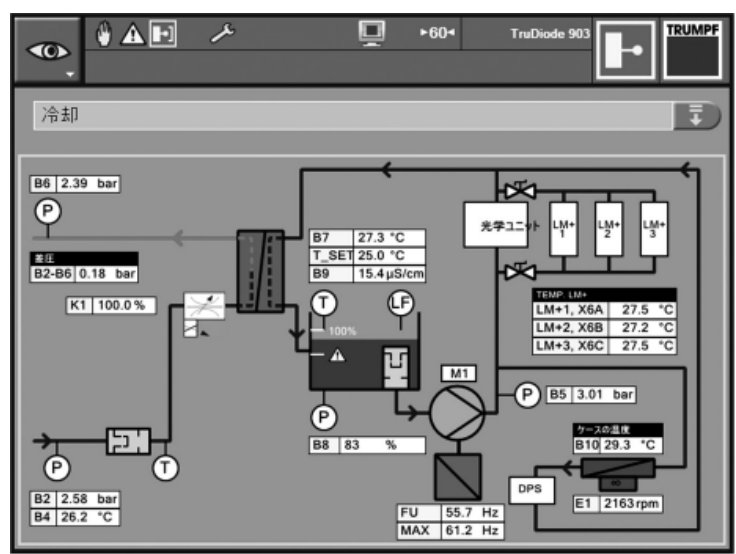

Fig.2 Temperature Monitoring Screen.

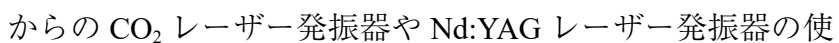
用者にとっては苦労の絶えない点であった。Fig.2に発振 器内の冷却水温度のモニタリング画面を示す。

今日の高性能かつ長寿命で堅牢性を兼ね備えた発振器の 登場により、その運用性が大きく向上した。しかしレーザー 性能を発揮して運用するには、まずはレーザー発振器の安 定発振が大前提であり、そのレーザー発振器本体の運転状 態をモニタリング・管理を行うことが重要である。

\section{2 溶接スキャナ用シームトラッキング}

従来のシームトラッキングは、ロボットに固定光学系を 保持させシームトラッキングセンサーと組み合わせて使用 するのが一般的であった ${ }^{2)}$ 。重称合せ溶接において、レー ザー溶接は従来のスポット溶接と比較してスポットガンの チップの大きさの制限がないことから、溶接部のフランジ 幅を狭隘化でき軽量化が可能であったが、重ね合せ溶接の 構造上フランジ幅はある程度必要であった。さらなる軽量 化のため、このフランジ部分をより小さくする手段の一つ として、重ね合せ溶接から隅肉溶接を採用する方法が考案 されている。しかしながら重ね合せ溶接から隅肉溶接にす ると位置決め精度の大幅な向上が必須となる。スポット径

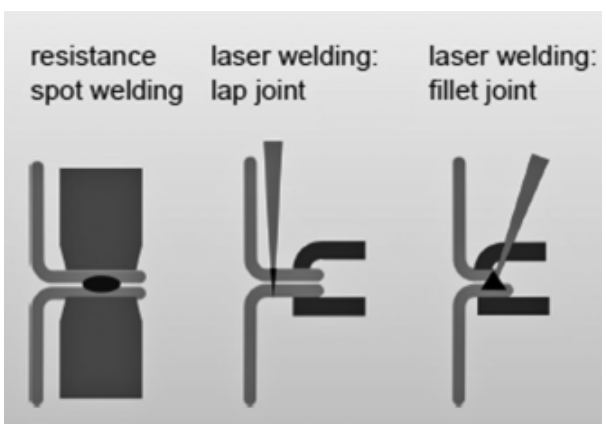

Fig.3 Flange Sizes Comparison Between the Different Processes.

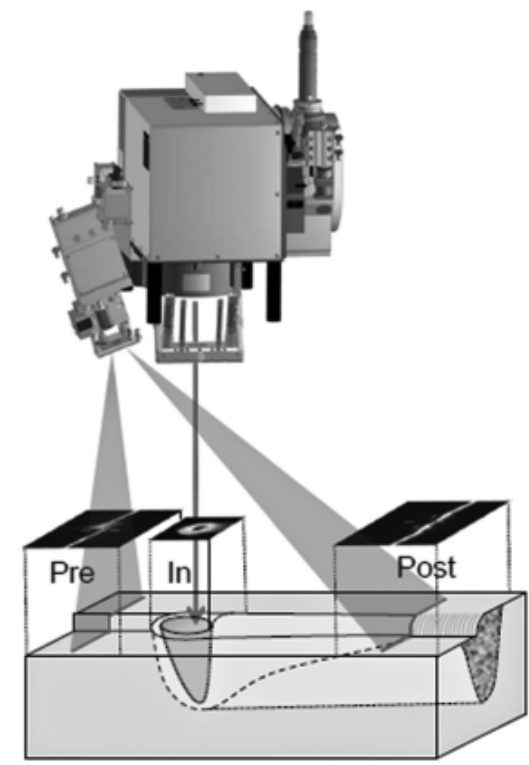

Fig.4 Principle of Scanner Tracking System.

の大きさの $1 / 10$ 程度の位置決め精度が必要と仮定すると、 $1 / 100 \mathrm{~mm}$ 程度の精度が必要になる。

Fig.3にフランジと各溶接方法を示す。

この精度をワーク側に求めることは現実的ではないた め、センサーによりシームトラッキングを行い、ビーム位 置を補正して、隅肉溶接部分に正確にレーザーを照射する ことが妥当となる。また、近年の溶接速度の高速化を勘案 し、スキャナとシームトラッキングシステムを組み合わせ るのが生産性の向上には不可欠である。

Fig.4に 3 次元スキャナとシームトラッキングを組み合わ せた基本構成を示す。レーザー溶接を開始する前に、3 次 元スキャナに搭載したシーム位置センシング用のレーザー を照射し、その反射光からシームの平面位置と高さ方向の ずれ量を測定して、そのずれ量をスキャナにフィードバッ クしレーザー照射位置を補正する。

Fig.5に測定結果の映像画面である。 


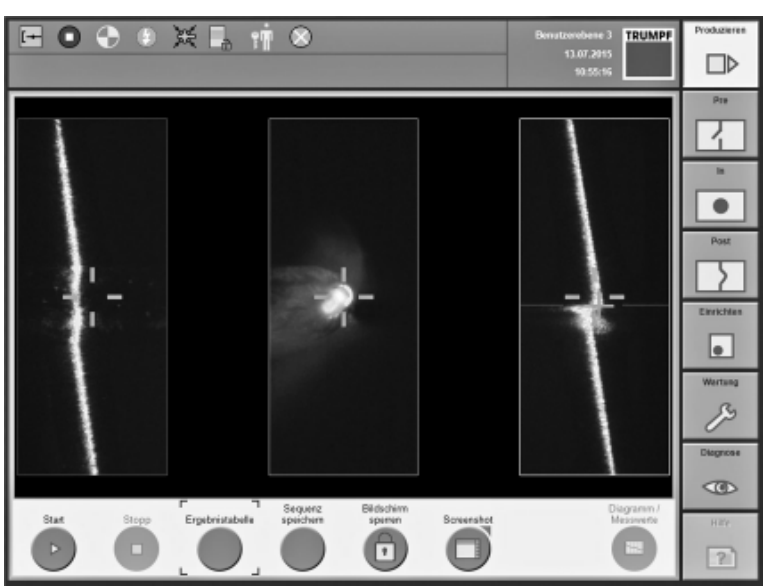

Fig.5 Measurement Result of Tracking System.

この補正機能を用いることにより、ワークや治具の位置 精度は従来のまま、所定の隅肉溶接部に正確にレーザー溶 接を施す事が可能となり、生産性の向上と軽量化を同時に 実現することが可能となる。

\section{3 リアルタイム溶融深さモニタリング}

レーザー溶接に限らず全ての溶接工程に扔いて、溶融深 度をインプロセスでモニタリングすることは永年の課題で あった。ここで紹介するリアルタイム溶融深さモニタリン グ装置は、リアルタイムでキーホール溶融深さをモニタリ ングし、一定溶融哚度を保つことで加工品質の安定に寄与 する技術である。レーザー加工は様々な要因により溶融深 度が変動する。

Fig.6にリアルタイムモニタリング装置の基本構成を示 す。測定用の半導体レーザーを使用し、キーホール底面か らの反射光を検出、別途設けられたワークピース表面まで の距離を模した光軸との差異を計測して、キーホール底面 までの距離を算出して溶融深度を測定している。

測定可能な溶融深度は深さ約 $6 \mathrm{~mm}$ 、キーホールのアス ペクト比約 20 まで可能である。

Fig.7にレーザー発振出力、本方式により測定した溶融 深度の測定值および断面エッチングにより実測した溶融深 度を示す。それぞれの值は近似しており、本方式による測 定は $0.2 \mathrm{~mm}$ 以下の精度で可能である。

このような溶融深度を一定に保つリアルタイムモニタリ ング技術は一定加工品質を担保する一助となる。

\section{4 リアルタイム溶接良否モニタリング}

重㸚合せ溶接に抒いて、裏面にビードが視認できても接 合されていない事象が発生する。この原因は上板と下板の 間に重㸚合せが不十分で隙が生じ、レーザー溶接が高速で 行われた際に溶融金属が瞬時に凝固し溶融金属が下板まで 流れないなどの原因で発生する。この状態を目視検査での

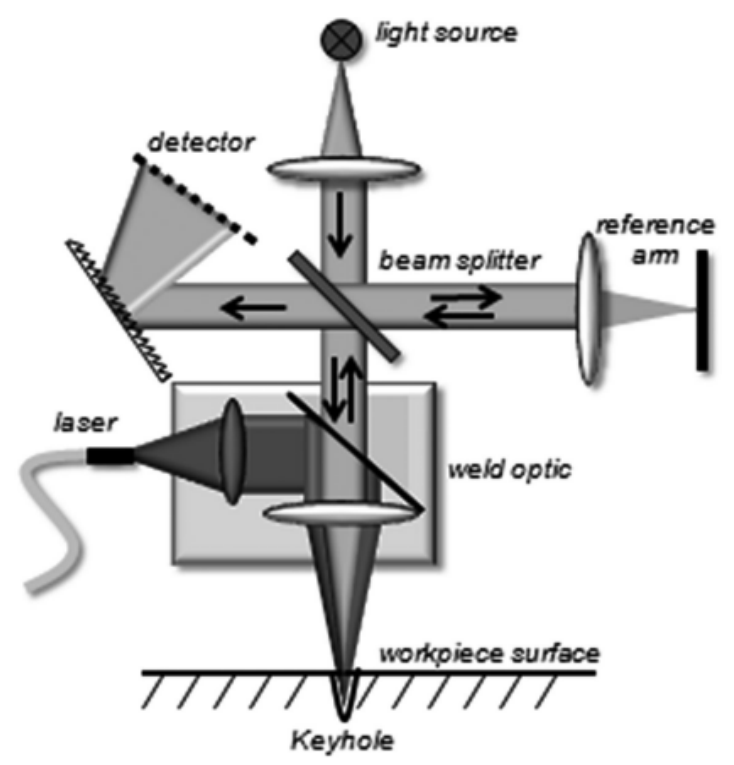

Fig.6 Principle of Real Time Welding Depth Monitoring System.

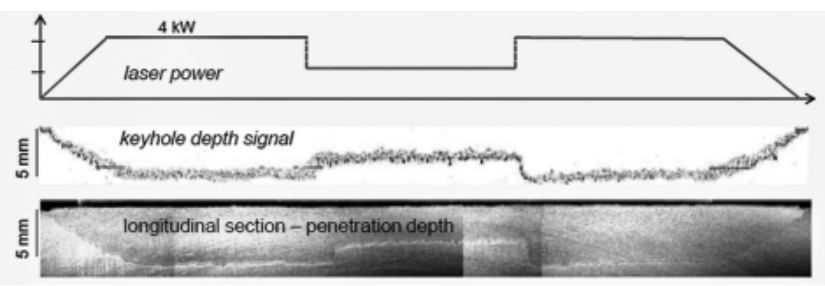

Fig.7 Measuring Results of Welding Depth.

判定することは困難である。

Fig.8にリアルタイム溶接良否モニタリング機器の基本 構造を示す。本技術は上板の熱容量の差を測定して判断す る技術で、重站合せが適切で下板への熱伝搬が十分の場合 の方が熱の拡散が速く溶接部の温度の低下が速い。これを 赤外線でスペクトルをモニタリングして良否判断するもの である。

Fig.9に良否比較を示す。正常な重ね合せ溶接の方の温 度が低くなっている。

固体レーザー波長 $1000 \mathrm{~nm}$ 付近の樹脂透過特性を利用 したレーザー樹脂溶着は、既に産業界でも広く浸透してい る。Fig.10 に樹脂溶着のプロセスを示す。レーザー光透過 性を持った上部樹脂側よりレーザーを照射し、下部にある 吸収性を持った樹脂表面でレーザー光の吸収・発熱を促し、 加圧した上で熱伝導を利用して両樹脂を溶着する技術であ る。しかし樹脂溶着は不純物の介在、隙間の存在、温度や 加圧の不均一で気泡が発生し易く、強度や美観の低下が発 生し易い。Fig.11にレーザー樹脂溶着プロセス時の問題点 を示す。 


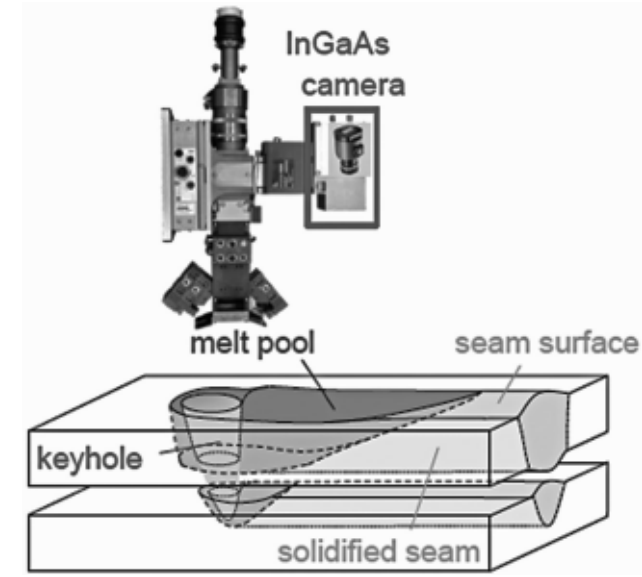

Fig.8 Principle of Lap Welding Monitoring System.
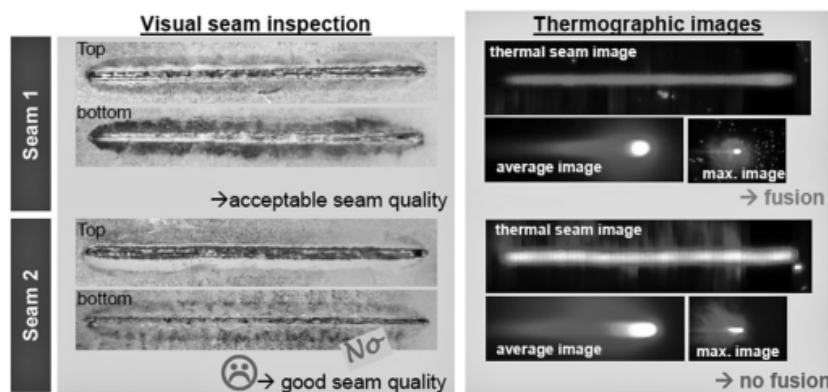

Fig.9 Measuring Results of Lap Welding.

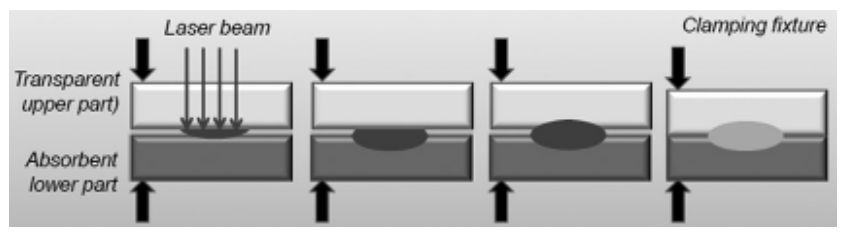

Fig.10 Function Principle of Transmission Welding in Plastic.

そこで樹脂溶着を実施する際には温度コントロールが重 要となる。Fig.12にパイロメーターを装備したリモートス キャナを示す。レーザー樹脂溶着時にレーザー照射箇所の 温度をリアルタイムで測定する装置である。

温度変化を察知した場合はレーザー発振器へフィード バックコントロールを行い、レーザー出力を増減させて接 合品質を補完する装置であり、その温度測定範囲は200〜 $520{ }^{\circ} \mathrm{C}$ である。

現在においてレーザー樹脂溶着は気密性を求められる部 品への応用が主であるが、今後は自動車の軽量化ニーズに 伴いその応用範囲の拡大が見込まれるが、その他の溶接 . 接合ニーズ同様にモニタリング技術の要求が見込まれる。

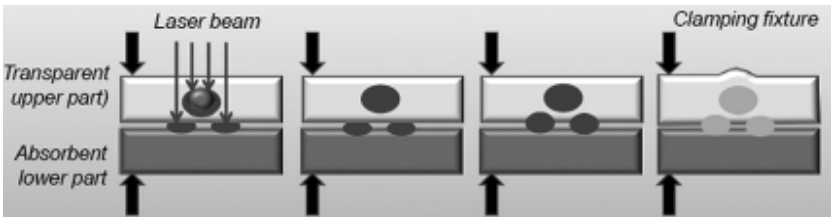

Fig.11 Problems During Transmission Welding.

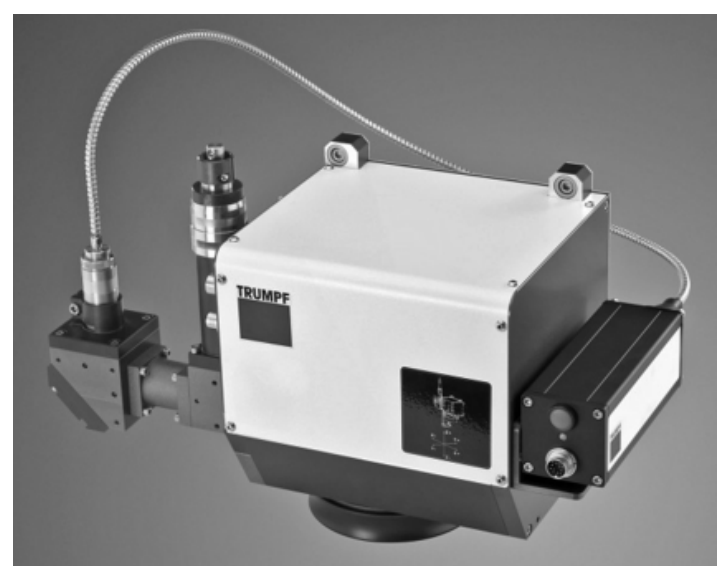

Fig.12 Scanner with Pyrometer.

2.5 加工端レーザー出力自動校正

半導体レーザー励起方式のレーザー発振器の普及により ランプ励起方式時代に比較し、レーザー発振器自体の出 力安定性は著しく向上した。しかしながら加工端部の集光 光学系の保護ガラスの污染に起因する加工端レーザー出力 の低下は、レーザー溶接品質低下や集光光学系破損の大き な要因である。保護ガラス表面の污染はクロスジェット等 の保護策を施しても完全には回避できず、生産現場におい ては保護ガラスの定期的点検、クリーニングと交換を適時 行う必要がある。Fig.13に自動加工点出力測定装置を示 す。本装置は、加工端出力をユーザーの任意設定の頻度で 自動測定を実施し、その測定結果を自動で発振器へフィー ドバックして加工端出力を設定值に校正する。発振器が フィードバックの出力限界に達した際は、保護ガラス交換 のアラームを発するシステムである。同じワークを連続加 エしても、ワーク表面に付着したオイルやバリ等の状態に よって、保護ガラス表面の污染度合は変化するが、自動測 定することにより保護ガラス表面の污染状況が受動的に知 ることができる。

\section{3. 情報化への取り組み}

今まで述べてきたモニタリング技術は、単一の発振器や 単一加工プロセスのモニタリングに過ぎない3)。しかし同 時に大量の情報を得ることができ、これらの情報を総合的 


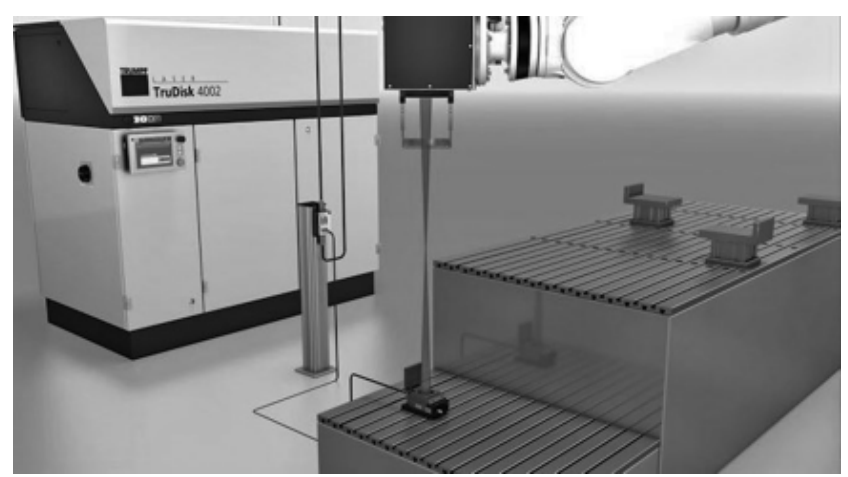

Fig.13 Automatic Laser Power Measurement.

に活用することで、過去に成し得なかった情報網を構築す ることが可能となる。

現在 IoT の潮流に関連し、Fig.14に欧州での Industry 4.0 のバリューチエインを示す。様々な機器と拠点をネットワー ク接続して、リアルタイムで接続機器を常時監視して運用 状況確認し、ワールドワイドで生産調整、コスト削減や物 品の調達、製品出荷前後の品質管理やトレーサビリティの 確認に活用するシステムの運用が急速に普及しつつある。 将来的にはこれらのビックデータを活用し、各機器の不具 合の兆候をいち早く察知して予防保全に活用し、機器の停 止時間を最小限に抑える一助として期待されている。

これらの情報を工程単位、工場単位または一企業単位で 活用する場合には社内の情報セキュリティ管理で実施可能 であり、大きな問題は見られないが、欧州で実施されてい る Industry 4.0 の様に設備メーカーやサプライチェーンをも 巻き込んだ大規模な IoT の構築を行㧍うとした場合、情報 管理の徹底は極めて重要な課題である。

この様な課題克服のため、例えば遠隔診断を実施する際 にドイッでは Fig.15に示す対策が施されている。

顧客とトルンプの間にはそれぞれ異なったセキュリティ が設けられているため、直接のネットワーク接続はでき ない。そこでセキュリティ化された顧客情報を一旦テレプ レゼンスプラットフォームまたはクラウドに預け、その情 報をトルンプでプラットフォームから拾い上げる方式であ る。顧客側では全ての情報をプラットフォームに預けるの ではなく、任意で提供可能な情報のみを抽出できるので、 外部へは知られたくない情報を開示する必要は無い。

\section{4. まとめ}

今回紹介したモニタリング装置は、一部を除き開発途上 の装置である。また欧州では既に Industry 4.0 の活動を開始 しているが、日本では IoT 関連の活動は一部企業に留まる。 情報化への取り組みはレーザー加工のみに限らず、複雑化 する生産工程に関連する全ての機器におよび、その情報の

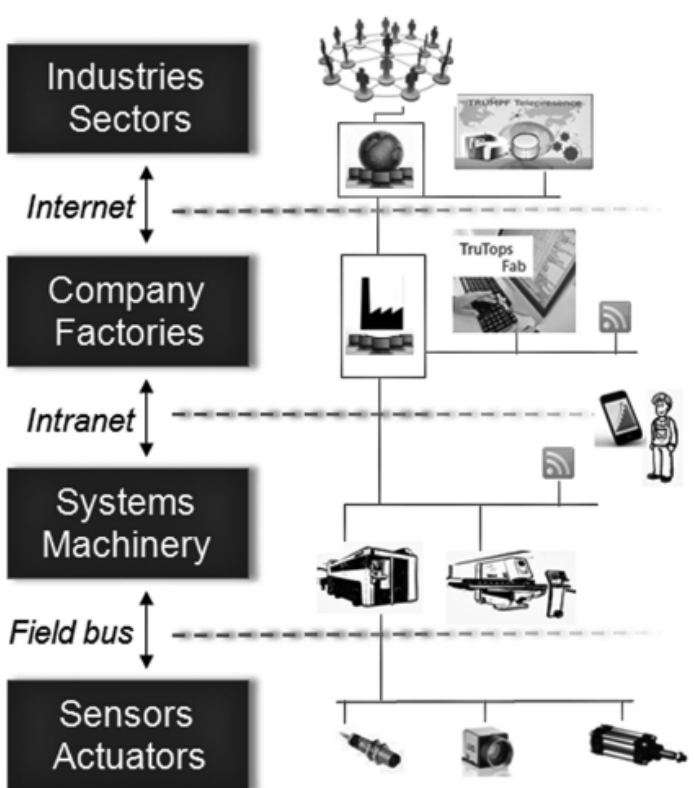

Fig.14 Intelligent Value Chains.

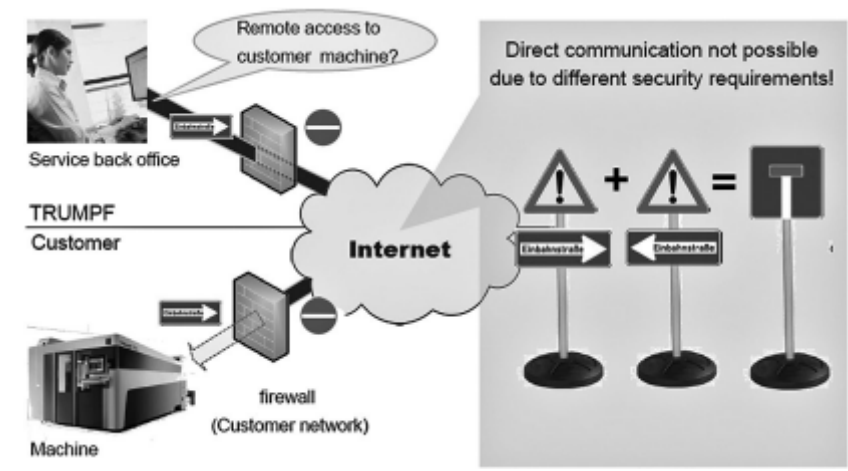

Fig.15 Remote Service.

活用範囲は一企業に留まらず、包括的なサプライチェーン 全体に及ぶものである。

本稿で紹介した情報化への取り組みが、今後導入を検討 している各位の導入の一助になれば幸いである。

\section{引用文献}

1) Geisen. A, Hügel. H, Voss. A, Wittig. K, Brauch. U and Opower. H: Scalable Concept for Diode-Pumped High-Power Solid-State Lasers, Appl. Phys. B, 58 (1994) 365-372.

2) Nakamura. T: Intelligent Laser System Based on Sensor and Monitoring Technology, Proceeding of the $85^{\text {th }}$ Laser Materials Processings Conference, (2016) 97-101.

3) Mizobe. H: Intelligence in laser processing, Proceedings of the $86^{\text {th }}$ Laser Materials Processing Conference, (2016) 85-88. 